\title{
Zasady opodatkowania umów sprzedaży maszyn rolniczych przez rolników ryczałtowych ${ }^{1}$
}

\begin{abstract}
Taxation rules regarding contracts of sale of agricultural machinery by flat-rate farmers: Contract of sale of agricultural machinery, concluded between two flat-rate farmers (the seller and the purchaser) will not be subject to the tax on civil law transactions. A farmer conducting a business activity - within the meaning of the VAT Act - may benefit from an exemption from the VAT tax as a flat-rate farmer (who delivers agricultural products originating from own agricultural activity or provides agricultural services), as well as a personal exemption which is described in the act regarding the so-called small taxpayers.
\end{abstract}

Keywords: farmer, Value Added Tax

Słowa kluczowe: rolnik, podatek VAT

Doktor nauk prawnych, ekspert ds. finansów publicznych BAS -

jacek.kulicki@sejm.gov.pl • https://orcid.org/0000-0003-2631-6428

\section{Przedmiot opinii}

Opinia zawiera odpowiedź na pytanie: „czy zakup przez rolnika ryczałtowego od rolnika ryczałtowego - którzy zwolnieni są od podatku od towarów i usług - maszyny rolniczej podlega opodatkowaniu podatkiem od czynności cywilnoprawnych na podstawie art. 2 ust. 4 lit. b ustawy o podatku od czynności cywilnoprawnych?".

Stan faktyczny, który był podstawą pojawienia się powyższych wątpliwości, został przedstawiony następująco: „rolnik ryczałtowy prowadzący gospodarstwo rolne nabył na podstawie umowy kupna-sprzedaży używaną maszynę rolniczą ciągnik rolniczy - od rolnika ryczałtowego prowadzącego gospodarstwo rolne. Maszyna ta wykorzystywana będzie na potrzeby własnego gospodarstwa rolne-

1 Opinia prawna $w$ sprawie zasad opodatkowania umów sprzedaży maszyn rolniczych przez rolników ryczałtowych sporządzona 7 lutego 2019 r. na zlecenie posła Klubu Parlamentarnego Prawo i Sprawiedliwość; BAS-WASiE 87/19. 
go. Sprzedający i kupujący dokonują dostawy produktów rolnych lub świadczą usługi rolnicze, które są zwolnione od podatku na podstawie art. 43 ust. 1 pkt 3 ustawy o podatku od towarów i usług".

\section{Analiza obowiązującego stanu prawnego w odniesieniu do przedstawionego stanu faktycznego}

W zakresie objętym pytaniem zastosowanie będą miały przepisy ustaw:

- z 9 września 2000 r. o podatku od czynności cywilnoprawnych, t.j. Dz.U. 2017, poz. 1150, ze zm.; dalej: u.p.c.c.,

- z 11 marca 2004 r. o podatku od towarów i usług, t.j. Dz.U. 2018, poz. 2174, ze zm.; dalej: u.p.t.u.

Podatkowi od czynności cywilnoprawnych podlegają m.in. umowy sprzedaży oraz zamiany rzeczy i praw majątkowych (art. 1 ust. 1 pkt 1 lit. a u.p.c.c.), przy czym - zgodnie z art. 1 ust. 4 u.p.c.c. - czynności te (umowy) podlegają opodatkowaniu, jeżeli ich przedmiotem są:

- rzeczy znajdujące się na terytorium Rzeczypospolitej Polskiej lub prawa majątkowe wykonywane na terytorium Rzeczypospolitej Polskiej,

- rzeczy znajdujące się za granicą lub prawa majątkowe wykonywane za granicą, w przypadku gdy nabywca ma miejsce zamieszkania lub siedzibę na terytorium Rzeczypospolitej Polskiej i czynność cywilnoprawna została dokonana na terytorium Rzeczypospolitej Polskiej.

Zgodnie z art. 2 pkt 4 u.p.c.c. podatkowi od czynności cywilnoprawnych nie podlegają czynności cywilnoprawne inne niż umowa spółki i jej zmiany:

- w zakresie, w jakim są opodatkowane podatkiem od towarów i usług (lit. a),

- jeżeli przynajmniej jedna ze stron jest zwolniona od podatku od towarów i usług z tytułu dokonania tej czynności (lit. b), z wyjątkiem:

- umów sprzedaży i zamiany, których przedmiotem jest nieruchomość lub jej część, albo prawo użytkowania wieczystego, spółdzielcze własnościowe prawo do lokalu, prawo do domu jednorodzinnego w spółdzielni mieszkaniowej lub prawo do miejsca postojowego w garażu wielostanowiskowym lub udział w tych prawach,

- umów sprzedaży udziałów i akcji w spółkach handlowych.

Z treści art. 2 pkt 4 u.p.c.c. wynika, że opodatkowaniu podatkiem od czynności cywilnoprawnych nie podlegają m.in. umowy sprzedaży rzeczy i praw majątkowych w dwóch przypadkach:

- jeżeli są opodatkowane podatkiem od towarów i usług (co istotne - tylko w zakresie, w jakim są opodatkowane tym podatkiem), 
- jeżeli przynajmniej jedna ze stron czynności cywilnoprawnej (w tym przypadku umowy sprzedaży) jest zwolniona z podatku od towarów i usług z tytułu dokonania tej czynności (wyjątek dotyczy niektórych umów wskazanych expressis verbis $\mathrm{w}$ art. 2 pkt 4 lit. b u.p.c.c.).

Wyłączenie z przedmiotowego zakresu podatku od czynności cywilnoprawnych m.in. umów sprzedaży $\mathrm{w}$ warunkach określonych $\mathrm{w}$ art. 2 pkt 4 u.p.c.c. odnosi się wyłącznie do tych czynności cywilnoprawnych (tych umów), które są bądź opodatkowane podatkiem od towarów i usług, bądź od podatku tego zwolniona jest jedna ze stron umowy, ale tylko w zakresie odnoszącym się do tej umowy. Bez znaczenia dla tego wyłączenia pozostaje „ogólny” status stron umowy w zakresie podatku od towarów i usług (podatnika, podatnika zwolnionego). Istotne jest, czy czynność cywilnoprawna (ta konkretna) jest opodatkowana podatkiem od towarów i usług lub czy jedna ze stron tej czynności korzysta ze zwolnienia od podatku od towarów i usług w odniesieniu do tej czynności².

Z przedstawionego opisu analizowanej sytuacji wynika, że stronami umowy sprzedaży ciągnika rolniczego są rolnicy mający dla celów podatku od towarów i usług status rolników ryczałtowych.

Zgodnie $\mathrm{z}$ art. 2 pkt 19 u.p.t.u. rolnikiem ryczałtowym dla celów podatku od towarów i usług jest rolnik dokonujący dostawy produktów rolnych pochodzących z własnej działalności rolniczej lub świadczący usługi rolnicze, korzystający ze zwolnienia od podatku od towarów i usług na podstawie art. 43 ust. 1 pkt 3 u.p.t.u., z wyjątkiem rolnika obowiązanego na podstawie odrębnych przepisów do prowadzenia ksiąg rachunkowych ${ }^{3}$.

Zgodnie $\mathrm{z}$ art. 43 ust. 1 pkt 3 u.p.t.u. od podatku od towarów i usług zwolniona jest dostawa produktów rolnych pochodzących $\mathrm{z}$ własnej działalności rolniczej dokonana przez rolnika ryczałtowego oraz świadczenie usług rolniczych przez rolnika ryczałtowego.

Sprzedaż maszyny rolniczej nie może być zaliczona ani do dostawy produktów rolniczych pochodzących z własnej działalności rolniczej ${ }^{4}$ sprzedającego, ani

2 Zob. Z. Ofiarski, Komentarz do art. 2 ustawy o podatku od czynności cywilnoprawnych, 2018, LEX, pkt 7, i przywołane tam orzecznictwo sądowe. Zob. również interpretacje indywidualne dyrektora Krajowej Informacji Skarbowej: nr 0111-KDIB4.4014.150.2 018.2.BB z 14 czerwca 2018 r. i nr 0111-KDIB4.4014.252.2018.4.DK z 18 września 2018 r., http://sip.mf.gov.pl/ [dostęp 6 lutego 2019 r.].

3 Zob. art. 2 ustawy z 29 września 1994 r. o rachunkowości (t.j. Dz.U. 2018, poz. 395, ze zm.) oraz art. 24a ustawy z 26 lipca 1991 r. o podatku dochodowym od osób fizycznych (t.j. Dz.U. 2018, poz. 1509, ze zm.).

4 Przez działalność rolniczą ustawa o podatku od towarów i usług rozumie produkcję roślinną i zwierzęcą, w tym również produkcję materiału siewnego, szkółkarskiego, hodowlanego oraz reprodukcyjnego, produkcję warzywniczą, gruntową, szklarniową i pod folią, produkcję roślin ozdobnych, grzybów uprawnych i sadowniczą, chów, 
do usług rolniczych, o których mowa w art. 43 ust. 1 pkt 3 u.p.t.u. (ich wykaz zawiera załącznik nr 2 do ustawy o podatku od towarów i usług, zob. art. 2 pkt 20 i 21 u.p.t.u.). Sprzedaż ta stanowi odrębną czynność cywilnoprawną, nieobjętą dyspozycją art. 43 ust. 1 pkt 3 u.p.t.u. Czynność ta może podlegać wyłączeniu z podatku od czynności cywilnoprawnych na podstawie art. 2 pkt 4 u.p.c.c. w dwóch przypadkach:

- w zakresie, w jakim jest opodatkowana podatkiem od towarów i usług (lit. a), - jeżeli przynajmniej jedna ze stron tej czynności jest zwolniona z podatku od towarów i usług z tytułu dokonania tej czynności (lit. b).

Zgodnie z art. 5 ust. 1 u.p.t.u. opodatkowaniu podatkiem od towarów i usług podlega m.in. odpłatna dostawa towarów i odpłatne świadczenie usług na terytorium kraju (pkt 1). Za dostawę towarów ustawa o podatku od towarów i usług rozumie przeniesienie prawa do rozporządzania towarami jak właściciel (art. 7 ust. 1 u.p.t.u.). Towarem zaś dla celów podatku od towarów i usług jest rzecz lub jej część (art. 2 pkt 6 u.p.t.u.). W tym kontekście należy więc uznać, że towarem w rozumieniu ustawy o podatku od towarów i usług jest również maszyna rolnicza, w tym ciągnik rolniczy, zaś sprzedaż takiej maszyny stanowi odpłatną dostawę towaru w rozumieniu art. 5 ust. 1 u.p.t.u.

Podatnikiem podatku od towarów i usług z tytułu takiej dostawy jest - zgodnie $\mathrm{z}$ art. 15 ust. 1 u.p.t.u. - osoba prawna, jednostka organizacyjna niemająca osobowości prawnej oraz osoba fizyczna, wykonująca samodzielnie działalność gospodarczą, o której mowa w art. 15 ust. 2 u.p.t.u., bez względu na cel lub rezultat takiej działalności.

Działalnością gospodarczą w rozumieniu ustawy o podatku od towarów i usług jest wszelka działalność producentów, handlowców lub usługodawców, w tym podmiotów pozyskujących zasoby naturalne oraz rolników, a także działalność osób wykonujących wolne zawody (art. 15 ust. 2 u.p.t.u.).

Reasumując, należy stwierdzić, że rolnik dokonujący odpłatnej dostawy towarów i usług prowadzi działalność gospodarczą w rozumieniu art. 15 ust. 2 u.p.t.u. Może on korzystać ze zwolnienia przedmiotowego z podatku od towarów

hodowlę i produkcję materiału zarodowego zwierząt, ptactwa i owadów użytkowych, produkcję zwierzęcą typu przemysłowego lub fermowego oraz chów i hodowlę ryb i innych organizmów żyjących w wodzie, a także uprawy w szklarniach i ogrzewanych tunelach foliowych, uprawy grzybów i ich grzybni, uprawy roślin „in vitro”, fermową hodowlę i chów drobiu rzeźnego i nieśnego, wylęgarnie drobiu, hodowlę i chów zwierząt futerkowych i laboratoryjnych, chów i hodowlę dżdżownic, entomofagów i jedwabników, prowadzenie pasiek oraz chów i hodowlę innych zwierząt poza gospodarstwem rolnym oraz sprzedaż produktów gospodarki leśnej i łowieckiej, Z wyjątkiem drewna okrągłego z drzew tropikalnych (PKWiU 02.20.13.0) oraz bambusa (PKWiU ex 01.29.30.0), a także świadczenie usług rolniczych (zob. art. 2 pkt 15 u.p.t.u.). 
i usług na podstawie art. 43 ust. 1 pkt 3 u.p.t.u. jako rolnik ryczałtowy (dokonujący dostawy produktów rolnych pochodzących z własnej działalności rolniczej lub świadczący usługi rolnicze), jak też ze zwolnienia podmiotowego, określonego w art. 113 u.p.t.u. (dla małych podatników).

Zgodnie $\mathrm{z}$ art. 113 u.p.t.u. od podatku od towarów i usług zwolniona jest sprzedaż dokonywana przez podatników, u których wartość sprzedaży nie przekroczyła łącznie w roku podatkowym kwoty 200000 zł (ust. 1). Co istotne, do wartości tej sprzedaży nie wlicza się, z pewnymi wyjątkami, niemającymi znaczenia dla odpowiedzi na pytanie będące podstawą tej opinii, odpłatnej dostawy towarów i odpłatnego świadczenia usług zwolnionych od podatku od towarów i usług na podstawie art. 43 ust. 1 u.p.t.u. (zob. art. 113 ust. 2 u.p.t.u.), a więc w przypadku rolników ryczałtowych wartości dostaw produktów rolnych pochodzących z własnej działalności rolniczej oraz wartości świadczonych usług rolniczych ${ }^{5}$. Istotne jest również to, że zwolnienie podmiotowe (z uwagi na wartość sprzedaży) nabywane jest przez podatnika prowadzącego działalność gospodarczą „z mocy prawa”, bez konieczności składania organowi podatkowemu oświadczenia o wyborze zwolnienia. Podatnik może natomiast zrezygnować ze zwolnienia podmiotowego, zawiadamiając o tym właściwy organ podatkowy, co powinno nastąpić przed początkiem miesiąca, w którym rezygnuje ze zwolnienia, a w przypadku podatników rozpoczynających w trakcie roku podatkowego wykonywanie czynności opodatkowanych podatkiem od towarów i usług, którzy chcą zrezygnować ze zwolnienia od pierwszej wykonanej czynności, przed dniem wykonania tej czynności (art. 113 ust. 4 u.p.t.u.).

Jeżeli podatnik korzysta ze zwolnienia podmiotowego na podstawie art. 113 u.p.t.u., to z podatku zwolniona jest tym samym każda czynność odpłatnej dostawy towarów i odpłatnego świadczenia usług dokonywana przez takiego podatnika, również - co do zasady - sprzedaż środka trwałego (np. maszyny rolniczej). Sprzedaż taka nie podlega także podatkowi od czynności cywilnoprawnych, bowiem korzysta z wyłączenia z przedmiotowego zakresu podatku od czynności cywilnoprawnych na podstawie art. 2 pkt 4 lit. b u.p.c.c. (jedna ze stron czynności zwolniona jest podmiotowo z podatku od towarów i usług, a tym samym korzysta ze zwolnienia od tego podatku w stosunku do tej czynności).

Jeżeli natomiast podatnik nie korzysta ze zwolnienia podmiotowego określonego w art. 113 u.p.t.u., to sprzedaż środka trwałego (np. maszyny rolniczej) może korzystać ze zwolnienia przedmiotowego na podstawie art. 43 ust. 1 pkt 2 u.p.t.u. Zgodnie z tym przepisem zwalnia się z podatku od towarów i usług dostawę towarów wykorzystywanych wyłącznie na cele działalności zwolnionej od podatku, jeżeli z tytułu nabycia, importu lub wytworzenia tych towarów nie przysługiwało dokonującemu ich dostawy prawo do obniżenia kwoty podatku

5 Zob. A. Bartosiewicz, Komentarz do art. 113 ustawy o podatku od towarów i ustug, 2018, LEX, pkt 5 i 6. 
należnego o kwotę podatku naliczonego. Również w takim przypadku umowa sprzedaży środka trwałego wyłączona będzie z przedmiotowego zakresu podatku od czynności cywilnoprawnych na podstawie art. 2 pkt 4 lit. b u.p.c.c. (jedna ze stron czynności zwolniona jest w stosunku do tej czynności z podatku od towarów i usług).

Jeżeli podatnik (sprzedający środek trwały) nie spełnia warunków z art. 113 u.p.t.u. (nie jest zwolniony podmiotowo z podatku od towarów i usług z uwagi na wartość sprzedaży) lub z art. 43 ust. 1 pkt 2 u.p.t.u. (środek trwały wykorzystywany wyłącznie na cele działalności zwolnionej od podatku), wówczas dostawa taka (sprzedaż środka trwałego) ${ }^{6}$ podlega opodatkowaniu podatkiem od towarów i usług. Tym samym wyłączona jest z opodatkowania podatkiem od czynności cywilnoprawnych na podstawie art. 2 pkt 4 lit. a u.p.c.c. w zakresie, w jakim podlega podatkowi od towarów i usług.

Odnosząc przedstawiony stan prawny do stanu faktycznego, będącego podstawą opinii, należy stwierdzić ${ }^{7}$ :

- jeżeli sprzedający maszynę rolniczą (ciągnik rolniczy) rolnik ryczałtowy korzysta jednocześnie ze zwolnienia podmiotowego, określonego w art. 113 u.p.t.u. (z uwagi na wartość sprzedaży), co wydaje się najbardziej prawdopodobne, to sprzedaż tego ciągnika nie jest objęta podatkiem od czynności cywilnoprawnych na podstawie art. 2 pkt 4 lit. b u.p.c.c. (rolnik ten jest bowiem zwolniony podmiotowo z podatku od towarów i usług i zwolnienie to obejmuje każdą czynność - dostawę towarów i świadczenie usług, dokonywane w ramach prowadzonej działalności),

- jeżeli sprzedający maszynę rolniczą (ciągnik rolniczy) nie korzysta ze zwolnienia z podatku od towarów i usług na podstawie art. 113 u.p.t.u. (z uwagi na wartość sprzedaży), a będąc rolnikiem ryczałtowym nabył sprzedawany ciągnik dla celów prowadzenia działalności zwolnionej od podatku od towarów i usług (taką działalnością jest działalność rolnika ryczałtowego) i nie przysługiwało mu $\mathrm{z}$ tego tytułu prawo odliczenia podatku naliczonego, to sprzedaż ta nie jest również objęta podatkiem od czynności cywilnoprawnych na podstawie art. 2 pkt 4 lit. b u.p.c.c. (z uwagi na zwolnienie tej czynności - dostawy ciągnika - z podatku od towarów i usług na podstawie art. 43 ust. 1 pkt 2 u.p.t.u.),

6 O ile nie jest elementem transakcji zbycia przedsiębiorstwa lub zorganizowanej jego części (art. 6 pkt 1 u.p.t.u.).

7 W pytaniu, będącym podstawą opinii, nie wskazano niestety, czy podatnik sprzedający maszynę rolniczą jest zwolniony od podatku od towarów I usług na podstawie art. 113 u.p.t.u. (zwolnienie ze względu na wartość sprzedaży). Wskazano jedynie, że sprzedający ciągnik rolniczy jest, podobnie jak i kupujący, rolnikiem ryczałtowym, zwolnionym od podatku od towarów i usług w zakresie dostaw produktów rolnych i świadczenia usług rolniczych na podstawie art. 43 ust. 1 pkt 3 u.p.t.u. 
- jeżeli rolnik ryczałtowy nie spełnia kryteriów zwolnienia $\mathrm{z}$ art. 113 u.p.t.u. oraz nie można zastosować dyspozycji art. 43 ust. 1 pkt 2 u.p.t.u. (zwolnienie z podatku dostawy towarów nabytych na cele wykonywania działalności zwolnionej z podatku od towarów i usług), wówczas sprzedaż maszyny rolniczej (ciągnika) będzie podlegać podatkowi od towarów i usług ${ }^{8}$, a tym samym wyłączona będzie z podatku od czynności cywilnoprawnych na podstawie art. 2 pkt 4 lit. a u.p.c.c.

\section{Podsumowanie}

- Z treści art. 2 pkt 4 u.p.c.c. wynika, że opodatkowaniu podatkiem od czynności cywilnoprawnych nie podlegają m.in. umowy sprzedaży rzeczy i praw majątkowych w dwóch przypadkach: w zakresie, w jakim są opodatkowane podatkiem od towarów i usług; jeżeli przynajmniej jedna ze stron czynności cywilnoprawnej (w tym przypadku umowy sprzedaży) jest zwolniona z podatku od towarów i usług z tytułu dokonania tej czynności.

- Rolnik prowadzący działalność gospodarczą w rozumieniu art. 15 ust. 2 u.p.t.u. może korzystać ze zwolnienia przedmiotowego z podatku od towarów i usług na podstawie art. 43 ust. 1 pkt 3 u.p.t.u. jako rolnik ryczałtowy (dokonujący dostawy produktów rolnych pochodzących $\mathrm{z}$ własnej działalności rolniczej lub świadczący usługi rolnicze), jak też ze zwolnienia podmiotowego, określonego w art. 113 u.p.t.u. (dla małych podatników).

Odnosząc stan prawny wynikający z ustawy o podatku od czynności cywilnoprawnych i ustawy o podatku od towarów i usług do stanu faktycznego analizowanego w niniejszej opinii, należy stwierdzić, że umowa sprzedaży maszyny rolniczej zawarta między dwoma rolnikami ryczałtowymi (sprzedającym i kupującym) nie będzie - o ile nie jest elementem zbycia przedsiębiorstwa lub zorganizowanej jego części - podlegała opodatkowaniu podatkiem od czynności cywilnoprawnych $\mathrm{z}$ uwagi na dyspozycję art. 2 pkt 4 u.p.c.c.

\section{Bibliografia}

Bartosiewicz A., Komentarz do art. 113 ustawy o podatku od towarów i ustug, 2018, LEX. Ofiarski Z., Komentarz do art. 2 ustawy o podatku od czynności cywilnoprawnych, 2018, LEX.

$8 \quad$ Z zastrzeżeniem wynikającym z art. 6 pkt 1 u.p.t.u., który wyłącza z przedmiotowego zakresu podatku od towarów i usług transakcje zbycia przedsiębiorstwo lub zorganizowanej części przedsiębiorstwa. 